\title{
The Effect of Procarbazine on Leprosy
}

\author{
E. J. SCHULZ, M.MED (PRETORIA), D.P.H. \\ Research Assistant, Westfort Institution, Pretoria, and Lecturer in Dermatology, University of Pretoria
}

\section{GEOFFREY FALKSON, M.D. (PRETORIA)* \\ Senior Cancer Chemotherapist, Department of Cancer Chemotherapy, Pretoria Hospital}

\section{INTRODUCTION}

Following our experience of the effects of cyclophosphamide on leprosy and on the acute reactions of leprosy (Davison et al., 1964) it was decided at the end of 1963 to investigate the effect of procarbazine on this disease and its complications.

Procarbazine (N-isopropyl-alpha-(2-methylhydrazino)-p-toluamide hydrochloride N.S.C. 77213 ) is a methylhydrazine derivative of established value in the treatment of Hodgkin's disease. (Falkson et al., 1965.) It has been shown to suppress immune reactions (Hoffmann la Roche \& Co.) so that even if no antibacillary effect could be predicted, it was hoped that it would suppress erythema nodosum leprosum (E.N.L.).

\section{MATERIALS AND METHODS}

Eleven patients, 10 with lepromatous and 1 with reacting tuberculoid leprosy (no patients with borderline leprosy were included in this series) were treated with procarbazine. All patients received concomitant treatment with dapsone (average of $600 \mathrm{mgm}$. weekly) and 7 patients received intermittent prednisone for E.N.L. The age, sex and main clinical features of each patient as well as previous treatment are shown in Table 1.

At the start of treatment with procarbazine 4 of the 10 patients with lepromatous leprosy were recent admissions and had heavy infiltration of the skin with

nodules. The remaining 6 lepromatous patients had been given standard anti-leprosy therapy for from 107-292 weeks before the treatment with procarbazine was started. In these patients the lepromatous infiltrations were already diminishing, but they suffered from severe and continuous E.N.L.
Procarbazine, $50 \mathrm{mgm}$. by mouth 3 times per day, was given to the patients until the white cell count fell below 4000 per sq. $\mathrm{cm}$. When the white cell count again rose above 6000 per sq. $\mathrm{cm}$. treatment was resumed. Blood counts were done at weekly intervals. In Table 1 the total dose of procarbazine and the duration of administration is shown for each patient.

\section{RESULTS}

Despite the fact that leukopenia was induced in 10 of 11 patients no significant objective improvement was seen in the acute reactions of leprosy. Two of the 6 patients with erythema nodosum claimed that their lesions were less painful during procarbazine administration.

Reacting tuberculoid leprosy can be expected to resolve within months on standard treatment alone so that the improvement observed in patient No. 1 cannot be ascribed to procarbazine. Of the 10 patients with lepromatous leprosy there was marked clinical improvement in patients Nos. 2, 3, 4 and 5 who were new admissions with heavily infiltrated lesions. When procarbazine was discontinued their lesions continued to regress on dapsone alone. No unexpected change was observed in the 6 patients who had already been on treatment for long periods of time and whose infiltrations had already lessened previously.

Although the average bacterial indicest decreased in all patients following procarbazine

\footnotetext{
* In receipt of a grant from the National Cancer Association of South Africa.

$\dagger$ The bacterial index is calculated as follows: Smears are taken from 4 sites of affected skin. These are graded from $\frac{1}{2}$ (fewer than 10 bacilli in any one slide) to $4+$ (hundreds of bacilli per field). The highest possible count would therefore be 16 when the results of the 4 specimens are added together.
}

Procarbazine in Leprosy 
TABLE I

RESULTS OF TREATMENT OF LEPROSY WITH PROCARBAZINE

\begin{tabular}{|c|c|c|c|c|c|c|c|c|c|c|c|c|c|}
\hline \multirow[t]{2}{*}{ No. } & \multirow[t]{2}{*}{ Age } & \multirow[t]{2}{*}{ Sex } & \multirow{2}{*}{$\begin{array}{l}\begin{array}{l}\text { Type of } \\
\text { Leprosy }\end{array} \\
\begin{array}{l}\text { Reacting } \\
\text { Tuberculoid }\end{array}\end{array}$} & $\begin{array}{l}\text { Previo } \\
\text { Duration } \\
\text { in } \\
\text { weeks }\end{array}$ & \multirow[t]{2}{*}{$\begin{array}{l}\text { ous Treatment } \\
\text { Drugs }\end{array}$} & \multirow{2}{*}{$\begin{array}{l}\text { Clinical Findings } \\
\text { at start }\end{array}$} & $\begin{array}{l}\text { Duration } \\
\text { in } \\
\text { weeks }\end{array}$ & \multirow[t]{2}{*}{$\begin{array}{l}\text { Total } \\
\text { dose } \\
\text { in } \\
\mathrm{gm} .\end{array}$} & \multirow{2}{*}{$\begin{array}{c}\text { Lowest } \\
\text { white cell } \\
\text { count } \\
\text { per } \\
\text { sq. cm. }\end{array}$} & \multirow[t]{2}{*}{$\begin{array}{c}\text { Concomitant } \\
\text { Treatment }\end{array}$} & \multirow{2}{*}{\multicolumn{2}{|c|}{$\begin{array}{r}\text { A } \\
\text { Befor }\end{array}$}} & $\begin{array}{l}\text { Average } \\
\text { Bacterial } \\
\text { Indices }\end{array}$ \\
\hline & & & & & & & 36 & & & & & & 0 \\
\hline 2 & 30 & M & Lepromatous & & Dapsone & $\begin{array}{l}\text { Generalized infiltration of } \\
\text { skin; many raised plaques }\end{array}$ & 68 & 56.70 & 2450 & Dapsone & $\begin{array}{l}\text { Marked flattening of lesions } \\
\text { after } 3 \text { months. No reactions }\end{array}$ & 513 & $10 \frac{1}{2}$ \\
\hline 3 & 38 & $M$ & Lepromatous & 0 & None & $\begin{array}{l}\text { Heavy infiltration with } \\
\text { nodules }\end{array}$ & 38 & 16.8 & 2150 & Dapsone & $\begin{array}{l}\text { Marked clinical improve- } \\
\text { ment after } 5 \text { months. One } \\
\text { mild reaction (E.N.L.) I } 4 \\
\text { during treatment. Giddiness }\end{array}$ & $\begin{array}{ll}- & 14 \\
4 & \\
\text { ss } & \end{array}$ & 13 \\
\hline \multirow[t]{4}{*}{4} & & M & Lepromatous & 0 & None & $\begin{array}{l}\text { Generalized infiltration; } \\
\text { nodules on face }\end{array}$ & 49 & 44.1 & 4000 & $\begin{array}{l}\text { Dapsone } \\
\text { Prednisone }\end{array}$ & $\begin{array}{l}\text { Marked regression of } \\
\text { nodules after } 7 \text { months. } \\
\text { Transient rash apparently } \\
\text { due to dapsone. When } \\
\text { dapsone temporarily dis- } \\
\text { continued, mild E.N.L. } \\
\text { started }\end{array}$ & $\begin{array}{ll} & 16 \\
y & \\
- & \end{array}$ & 13 \\
\hline & & M & Lepromatous & 0 & None & $\begin{array}{l}\text { Heavy generalized infil- } \\
\text { tration with rugae plaques } \\
\text { and nodules }\end{array}$ & 62 & 39.0 & 2450 & Dapsone & $\begin{array}{l}\text { Marked clinical improve- } \\
\text { ment after } 5 \text { months. } \\
\text { Occasional mild E.N.L. } \\
\text { from start }\end{array}$ & 16 & \\
\hline & 32 & $M$ & Lepromatous & 168 & $\begin{array}{l}\text { Dapsone } \\
\text { Cyclophos- } \\
\text { phamide } \\
\text { Prednisone }\end{array}$ & $\begin{array}{l}\text { Subsiding generalized } \\
\text { infiltration of skin. Severe } \\
\text { continuous E.N.L. }\end{array}$ & 36 & 25.2 & 2000 & $\begin{array}{l}\text { Dapsone } \\
\text { Prednisone }\end{array}$ & $\begin{array}{l}\text { No significant improve- } \\
\text { ment in E.N.L. }\end{array}$ & & \\
\hline & 48 & $M$ & Lepromatous & 292 & $\begin{array}{l}\text { Dapsone } \\
\text { Prednisone } \\
\text { Thiambutosine } \\
\text { Cyclophos- } \\
\text { phamide }\end{array}$ & $\begin{array}{l}\text { Subsiding generalized } \\
\text { infiltration of skin. Severe } \\
\text { continuous and ulcerating } \\
\text { E.N.L. }\end{array}$ & 36 & 30.45 & 4100 & $\begin{array}{l}\text { Dapsone } \\
\text { Prednisone }\end{array}$ & $\begin{array}{l}\text { No improvement in E.N.L. } \\
\text { Attacks leprous neuritis }\end{array}$ & 0 & 0 \\
\hline \multirow[t]{2}{*}{8} & 50 & $M$ & Lepromatous & 208 & $\begin{array}{l}\text { Dapsone } \\
\text { Prednisone } \\
\text { Thiamazole } \\
\text { Cyclophos- } \\
\text { phamide }\end{array}$ & $\begin{array}{l}\text { Subsiding generalized } \\
\text { infiltration of skin. } \\
\text { Recurrent E.N.L. }\end{array}$ & 36 & 37.8 & 6050 & $\begin{array}{l}\text { Dapsone } \\
\text { Prednisone }\end{array}$ & $\begin{array}{l}\text { No improvement in } \\
\text { amount of E.N.L. } \\
\text { E.N.L. less painful }\end{array}$ & & \\
\hline & 60 & $M$ & Lepromatous & 208 & $\begin{array}{l}\text { Dapsone } \\
\text { Prednisone } \\
\text { Cyclophos- } \\
\text { phamide }\end{array}$ & $\begin{array}{l}\text { Generalized infiltration of } \\
\text { skin. Severe recurrent } \\
\text { E.N.L. }\end{array}$ & 36 & 31.5 & 3150 & $\begin{array}{l}\text { Dapsone } \\
\text { Prednisone }\end{array}$ & No improvement in E.N.L. & 4 & \\
\hline 10 & 25 & M & Lepromatous & 168 & $\begin{array}{l}\text { Dapsone } \\
\text { Prednisone } \\
\text { Cyclophos- } \\
\text { phamide }\end{array}$ & $\begin{array}{l}\text { Generalized infiltration of } \\
\text { skin. Almost continuous } \\
\text { E.N.L. and leprous neuritis }\end{array}$ & 36 & 24.15 & 2300 & $\begin{array}{l}\text { Dapsone } \\
\text { Prednisone }\end{array}$ & $\begin{array}{l}\text { No objective improvement } \\
\text { in E.N.L. but less painful. } \\
\text { Neuritis remained severe }\end{array}$ & 2 & \\
\hline 11 & 40 & M & Lepromatous & 107 & $\begin{array}{l}\text { Dapsone } \\
\text { Cyclophos- } \\
\text { phamide } \\
\text { Prednisone }\end{array}$ & $\begin{array}{l}\text { Generalized infiltration } \\
\text { with nodules. Severe E.N.L. } \\
\text { and neuritis }\end{array}$ & . & 17.85 & 2850 & $\begin{array}{l}\text { Dapsone } \\
\text { Prednisone }\end{array}$ & $\begin{array}{l}\text { No improvement in E.N.L. } \\
\text { or neuritis. Died of tuber- } \\
\text { culous bronchopneumonia. } \\
\text { White blood count } 11,400 \\
\text { at time of death }\end{array}$ & & \\
\hline
\end{tabular}

treatment, this was not beyond what might have been expected from dapsone alone. The bacterial indices for each patient are shown in Table 1.

One patient, No. 11, died during the time that he was receiving procarbazine. He was not leukopenic at the time of death and post mortem examination revealed lepromatous leprosy and caseating tuberculous bronchopneumonia. The only disadvantageous effect apart from leukopenia was giddiness in 1 patient (No. 3), for

\section{Leprosy Review}

which the treatment was stopped.

The lowest white cell count for each patient is shown in Table 1. Figure 1 shows the changes in the white cell count during procarbazine treatment in patient No. 2. Dapsone was not found to inhibit the development of leukopenia in patients receiving procarbazine, whereas dapsone inhibits the development of leukopenia in patients receiving cyclophosphamide. (Davison et al., 1964.) 


\section{DISCUSSION}

Dapsone (sodium 4'-4' diamino diphenyl sulphone) both brings about resolution of the lesions of leprosy and causes the bacilli to disintegrate. This response to dapsone may however only follow after years of treatment in the lepromatous type of the disease. During treatment acute reactions are apt to occur which may be debilitating. Although these reactions also occur without treatment, they are more common and more pronounced during treatment with dapsone. A drug is therefore needed which will cure the disease more rapidly without worsening the acute reactions. Many of the complications of lepromatous leprosy appear to be hyper-reactive phenomena. A drug which could supress these phenomena during dapsone administration would be of value.

E.N.L. is an acute reaction which occurs in about $30 \%$ of patients with lepromatous leprosy and occasionally in borderline patients. It is thought to be either the result of an allergic reaction to the breakdown products of leprosy bacilli, or to be a stress phenomenon (Muir, 1962).

Because cyclophosphamide markedly inhibits antibody production (Berenbaum, 1960, 1961 and 1962) a clinical trial with this agent in leprosy started in 1960. It was found that when large doses were used, although the lesions

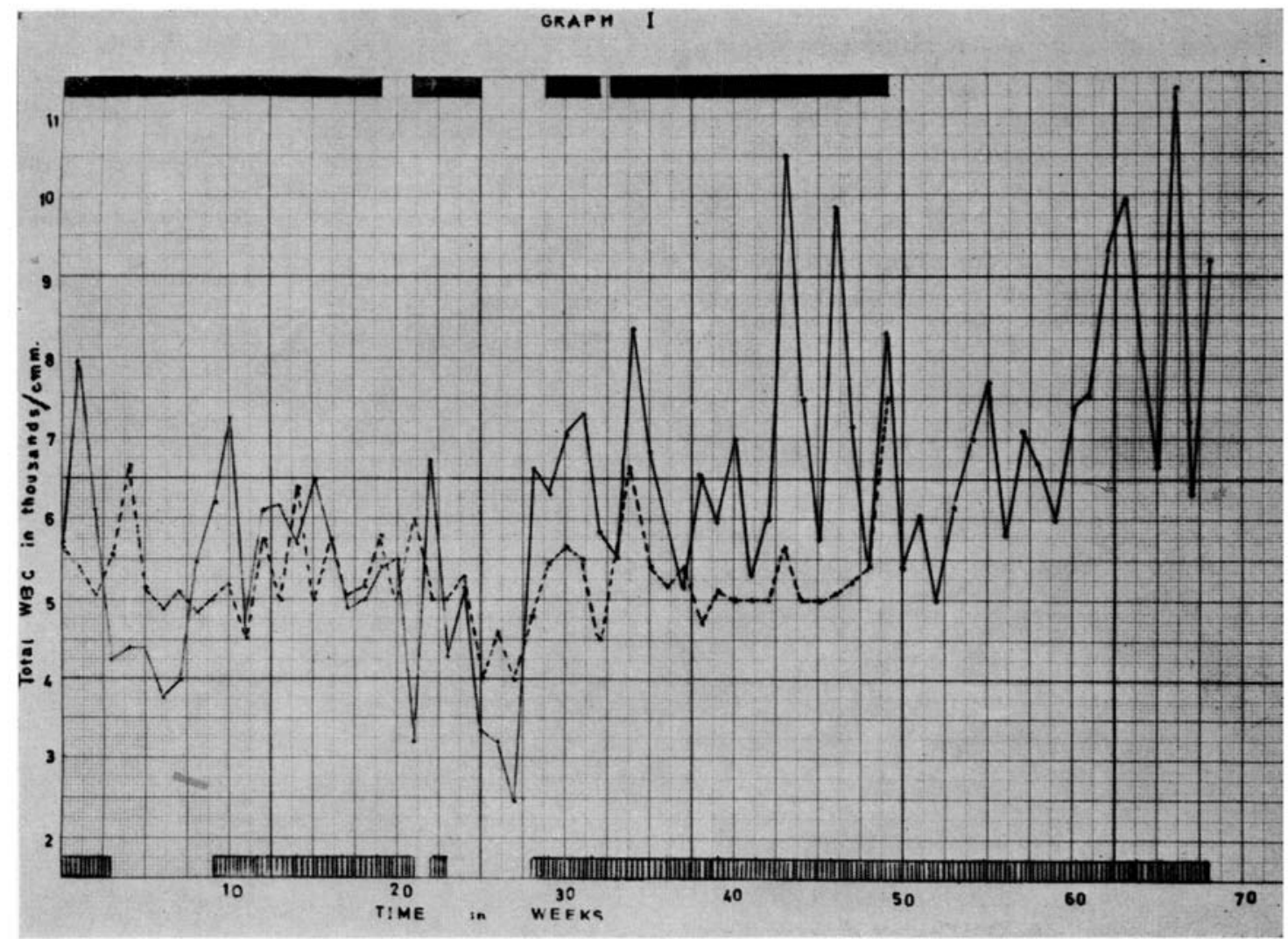

Legend to Graph 1

TOTAL WHITE CELL COUNT AND TIRATMENT

IN PATIENTS NOS. 2 AND 4

White cell count in Patient Number 4. $150 \mathrm{mg}$. procarbazine/day, Patient Number 4.
White cell count in Patient Number 2.
III $150 \mathrm{mg}$. procarbazine/day, Patient Number 2. 
regressed considerably, the bacillary content was not affected. Large doses of this agent did however inhibit acute reactions such as E.N.L. When small doses of cyclophosphamide (100 mgm. per day for from 98-146 days) were administered concomitantly with dapsone, no beneficial effect was observed from the cyclophosphamide.

Recently Mathews and Trautman (1965), after presenting evidence that leprosy has features of a collagen disease, suggested investigating the efficacy of antimetabolites in leprosy. They claimed extremely encouraging results in a limited number of patients following the use of azathioprene and methotrexate in patients complicated by erythematous exacerbation or necrotizing vasculitis.

The immuno-suppressive properties of cytostatic drugs vary with total dose and concentration. Because of the side effects involved in using a high dose of procarbazine (leukopenai, thrombocytopenia, nausea, vomiting, etc.) only a low dosage (150 mgm./day) was thought safe in this trial. Within this dose range no significant immuno-suppressive effects were observed in our leprosy patients.

\section{SUMMARY}

Eleven patients with leprosy were given low doses of procarbazine with dapsone from from 22-68 weeks. In 2 of 6 patients with severe recurrent E.N.L. the lesions became less painful, but no objective improvement was observed. In 5 patients with infiltrated lesions, resolution may have been hastened by the addition of procarbazine to standard treatment. Procarbazine did not significantly affect the bacterial indices.

This paper is published with the permission of the Secretary of Health, Department of Health, Republic of South Africa.

\section{REFERENCES}

Berenbaum, м. с. (1960). Nature, Lond., 185, 167.

Berenbaum, M. C. (1961). Path. Biol., 9, 963.

Berenbaum, M. C. (1962). Nature, Lond., $196,384$.

DAVison, A. R., SChUlz, E. J., FAlkson, G., EGNAL, M. L. (1964). Lancet, 2, 1138.

FAlkson, G., De villiers, P. C., FALkson, H. C. (1965). Cancer Chemother. Rep., 46, 7.

hoffman la roche and company, Personal Communication.

mathews, L. J., trautman, J. R. (1965). Lancet, 2, $7419,915$.

MUIR, E. (1962). Lep. Rev., 37, 240. 